\title{
Moderasi Agama dan Pemahaman Radikalisme di Indonesia
}

\author{
Priyantoro Widodo, Karnawati \\ Sekolah Tinggi Teologi Baptis Indonesia Semarang \\ priyantorowidodo@gmail.com, karnawatirejo@gmail.com
}

\begin{abstract}
ABSTRAK
Revolusi Industri 4.0 menyebabkan terjadinya disrupsi di berbagai bidang bisnis dan terus meluas pada bidang-bidang yang lain, termasuk pendidikan, pemerintahan, hukum, budaya, politik, sosial dan juga keagamaan. Dalam bidang keagamaan, implementasi pelaksanaan peribadatan pun turut terdisrupsi oleh perkembangan teknologi dan trend zaman. Hal ini memungkinkan terjadinya kemerosotan nasionalisme. Lalu bagaimana insitusi gereja menyikapinya. Penelitian ini bertujuan menjabarkan pengertian moderasi agama dan radikalisme yang tersebar melalui sarana informasi teknologi yang tak terbatas. Penelitian ini menggunakan metode studi pustakan dan pengamatan terhadap tindakan-tindakan radikal di Indonesia. Hasil penelitian ditemukan bahwa gerakan radikalisme di Indonesia muncul karena dipicu oleh persoalan domestik dan konstelasi politik internasional yang dinilai telah memojokkan kehidupan sosial politik umat islam. Dalam hal ini gereja tidak boleh tutup mata dan tidak peduli. Tetapi mengimplementasikan sikap untuk: mendalami agama Kristen secara teks alkitab yang mengajarkan tentang "kasih" dan harus bersikap pluralis terhadap agama dan masyarakat.
\end{abstract}

Kata Kunci: Moderasi, radikalisme

\section{PENDAHULUAN}

Era revolusi industry 4.0 merupakan era rekayasa intelegensia dan internet of thing sebagai tulang punggung pergerakan dan konektifitas manusia dan mesin. ${ }^{1}$ Era ini membawa dampak bagi perkembangan masyarakat. Masyarakat yang akan dan sedang dituju tersebut disebut masyarakat 5.0. Masyarakat 5.0 merupakan tatanan masyarakat yang berbasis teknologi dimana data-data terkompilasi di dunia maya yang dapat digunakan dalam segala bidang kehidupan (Arief Budiman, 2019). ${ }^{2}$

Era ini membawa dampak secara luas dan mendisrupsi berbagai bidang kehidupan manusia. Dimana manusia yang dulunya melakukan aktifitas di dunia nyata, namun oleh karena perkembangan teknologi

\footnotetext{
${ }^{1}$ Prasetyo, Jurnal of Proceedings Series: Prosiding SEMATEKSOS 3 "Strategi Pembangunan

Nasional MenghadapiRevolusiIndustri 4.0" . No 5 (2018). Hal 22-27
}

akhirnya menggeser aktifitas nyata tersebut menjadi aktifitas dalam dunia maya. Dari aktifitas di dunia maya tersebut, manusia tidak hanya dapat memenuhi kebutuhan-kebutuhan hidup sekarang, tetapi juga dapat mengenali, mengantisipasi dan mempersiapkan kebutuhankebutuhan di masa yang akan datang.

Praseto dalam jurnalnya menyimpulkan bahwa revolusi industry 4.0 menyebabkan disrupsi pada berbagai bidang mulai pada bidang bisnis kemudian juga meluas pada bidangbidang yang lain, diantaranya pendidikan, pemerintahan, hukum, budaya, politik, dan sosial (prasetyo;2019).

Pada dasarnya nilai sosial yang dianut dalam masyarakat terpengaruh dari budaya dan keyakinan yang dianut dalam masyarakat di suatu wilayah tersebut. Dengan demikian bidang 
keagamaanpun dalam implementasi pelaksnaan peribadatan turut terdisrupsi oleh perkembangan teknologi zaman. Hal ini memungkinakan terjadinya kemerosotan nasionalisme. Nilai-nilai luhur yang menjadi dasar pembangunan bangsa Indonesia yaitu Pancasila, bisa saja tergerus oleh kemajuan teknologi. Karena teknologi bebas memberi pengetahuan dan tayangan melalui bidang penyiaran nilai-nilai radikalisme. Lalu bagaimana insitusi keagamaan menyikapinya.

Dengan latar belakang tersebut, maka tulisan ini berusaha membahas tentang bagaimana seharusnya gereja yang berada di wilayah Negara Kesatua Republik Indonesia yang plural ini dapat menerapkan ajarannya yang inklusif namun tetap menjaga prisip moderasi agama dan dan bagaimana gereja memahami konsep radikalisme, sehingga dapat mengambil suatu langkah eksplisit yang efektif dalam menanggkalnya.

\section{METODE PENELITIAN}

Penelitian ini menggunakan studi kepustakaan, yaitu dengan mengumpulkan berbagai informasi mengenai radikalisme dari berbagai jurnal dan opini dari kalangan akademisi yang melakukan penelitian di berbagai negara di belahan dunia. Disamping itu membuat kesimpulan atas perilaku masyarakat yang diamati. Dari hasil kajian dan pustaka, selanjutnya dilabuat sebuah kesimpulan untuk mendapatkan rekomendasi atas persoalan perlunya moderasi agama dan bagaimana menanggulangi radikalisme di Indonesia.

\section{PEMBAHASAN}

\section{Moderasi Agama}

Istilah moderasi diambil dari bahasa وَسَ طُ طarabik dari akar kata yang sama yaitu yang artinya tengah atau moderat. Dalam islam berarti menyatakan watak Islam adalah moderat dalam hal bertindak dan moderat dalam segala urusan baik, tindakan, ucapan, atau pikiran. ${ }^{3}$

Sedangkan Dalam bukunya, The Middle Path of Moderation in Islam
(Oxford University Press, 2015), Mohammad Hashim Kamali menegaskan bahwa moderate, yang dalam bahasa Arab berarti "wasathiyah", tidak dapat dilepaskan dari dua kata kunc, yakni berimbang (balance), dan adil (justice). Moderat bukan berarti kompromi dengan prinsip-prinsip pokok ushuliyah) ajaran agama yang diyakini demi bersikap toleran kepada umat agama lain; moderat berarti “... confidence, right balancing, and justice..." (halaman 14). Tanpa keseimbangan dan keadilan seruan moderasi beragama akan menjadi tidak efektif.

Imam Shamsi Ali menyimpulkan bahwa moderasi itu adalah komitmen kepada agama apa adanya, tanpa dikurangi atau dilebihkan. Agama dilakukan dengan penuh komitmen, dengan mempertimbangkan hak-hak vertikal (ubudiyah) dan hak-hak horizontal (ihsan).

Anis Malik Thoha mengatakan bahwa muslim moderat adalah seorang muslim yang memenuhi islamik prinsiple wassatiyah (prinsip moderasi dalam islam) antara lain tidak ekstrim kanan maupun kiri. Hal ini berarti bahwa muslim harus mampu menjaga dirinya untuk tidak menggunakan kekerasan, melainkan membawa kedamaian dan rahmat untuk semua alam; juga memahami bahwa islam memiliki hukum yang bersifat tetap dan ada yang bisa berubah atau diijtihadkan sesuai perkembangan jaman; tidak menggunakan pemaksaan; tidak mengkompromikan hal-hal dasar dalam agama hal ini untuk menjaga kesucian beragama; mengkompromikan hal-hal yang bersifat fundamental dalam beragama yaitu hidup rukun berdampingan dengan siapapun.

Tim Kementrian Agama RI menyebutkan bahwa kemajemukan di berbagai kondisi di Indonesia sangat diperlukan suatu sistem pengajaran agama yang komprehensif yang dapat mewakili setiap orang yang ada melalui ajaran yang luwes dengan tidak meninggalkan teks, serta pentingnya penggunaan akal sebagai solusi dari setiap masalah yang ada.

Dalam realitas kehidupan beragama di Indonesia. Agama Islam dominan memiliki pandangan yang berperilaku ekstrem (fanatik) dalam pemahaman dan pengalaman beragama yang dikenal dengan kelompok ekstrem kanan dan ekstrem kiri. Menurut Hilmi, kedua kelompok ini tidak akan pernah mampu

\footnotetext{
3 (Achmad Yusuf; Jurnal Pendidikan agama islam).
} 
memosisikan diri sebagai khalifatun ardh, terlebih lagi menjadi rahmat bagi segenap alam.

Ahmad Yusuf dalam kajiannya berpendapat bahwa sebenarnya Islam adalah agama yang wasathan. Wasathan dalam trilogi Islam yaitu moderasi Islam yang memiliki tiga dimensi meliputi: (1) dimensi aqidah meliputi (a) ketuhanan antara Atheisme dan Poletheisme, (b) alam antara kenyataan dan khayalan, (c) Sifat Allah antara Ta ${ }^{e e}$ thîl dan Tasybîh, (d) Kenabian antara Kultus dan Ketus, (e) Sumber Kebenaran antara Akal dan Wahyu, (f) Manusia di antara al-Jabr dan al-Ikhtiyar.

(2) dimensi syarieeah, meliputi (a) Ketuhanan dan Kemanusiaan (b) Idealitas dan Realitas (c) Tahlil dan Tahrim, (d) Kemaslahatan Individu dan Kolektif, (e) Ketegasan dan Kelenturan dan (3) di bidang Tasawuf meliputi Syari at dan Hakikat, (b) Khauf dan Raja', (c) Jasmaniyah dan Ruhaniyah, (d) Zhahir dan Bathin.

Sedangkan Nur Kolis memberi sebuah kesimpulan berdasarkan gagasan tokoh sufi ternama Husin Mansur al-Hallaj dan Muhryi al-Din Ibn 'Arabi, bahwa pemikir sufistik wahdat al-adyan menawarkan satu gagasan moderat yang humanis, dan universal dalam konteks relasi agama-agama, dimana didalamnya terkandung pesan moral yang terkait secara langsung dengan masalah harmoni kehidupan sosial keagamaan. ${ }^{4}$

Hal ini diperkuat oleh penelitian Dzikir Manaqib yang mengatakan bahwa moderasi Islam tidak berarti berada pada posisi netral yang abu-abu, sebagaimana yang sering dialamatkan kepada term tersebut, tidak juga berarti bahwa moderasi Islam diidentikan dengan paradigma Barat yang cenderung memperjuangkan bahkan membuka kebebasan yang kebablasan. Akan tetapi moderasi Islam yang dimaksud adalah nilai-nilai universal seperti keadilan, persamaan, kerahmatan, keseimbangan yang dimiliki oleh agama Islam yang memiliki akar sejarah yang kuat dalam

\footnotetext{
${ }^{4}$ Moderasi Sufistik atas Pluralitas Agama

Nur Kolis. Jurnal pemikiran keislaman dan

Kemanusiaan BO. 1 No 2 Oktober 2017. 166-180
}

tradisi Nabi dan Sahabat. Moderasi Islam seperti itu kemudian dapat dijumpai dalam setiap disiplin keilmuan Islam, mulai dari perspektif aqidah Islam, pemikiran Islam dan moderat tasawuf. ${ }^{5}$

Konteks moderat yang diyakini umat islam membuahkan pemikiran untuk membuat sebuah kurikulum yang sesuai dengan tujuan moderasi agama di Indonesia. Sauqi Futaqi memberi gagasan sebuah pendekatan kurikulum pendidikan islam yang moderat dengan menggunakan pendekatan: (1) kontributif, yaitu dengan menyisipkan konten tertentu dalam mata pelajaran seperti tokoh-tokoh islam nusantara, yang memiliki pemikiran dan sikap moerat; (2) adiktif, yaitu dengan menambah konten, konsep, tema, dan perspektif ke dalam kurikulum tanpa mengubah struktur dasar, tujuan, dan karakteristik kurikulum; (3) transformatif, yaitu dengan merubah tujuan mendasar, struktur, dan perspektif kurikulum, sehingga memungkinkank peserta didik melihat konsep, isu, tema, dan masalah dari berbagai sudut pandang; (4) aksi sosial, yaitu mencakup semua elemen pendekatan transformatif namun meambahkan komponen yang mengharuskan peserta didik membuat keputusan dan mengambil tindakan yang terkait dengan konsep dan masalah yang dihadapi. Adapun tujuan utama pembelajaran dengan pendekatan ini adalah untuk mendidik peserta didik melakukan kritik sosial, perubahan dan keterampilan membuat keputusan. ${ }^{6}$

Indonesia adalah negara yang terkenal kaya akan keberanekaragaman. Mulai dari ras, suku, budaya, agama, Bahasa, dan sebagainya. Dari hal ini sangat mungkin sekali menimbulkan konflik. Namun sejarah telah membuktikan, bahwa ada sebuah usaha untuk membuat aneka ragam hal ini berinteraksi dengan teratur. Hal ini dirumuskan dalam sebuah dasar negara yaitu Pancasila. Pancasila menghendaki keberbedaan menjadi satu dalam konteks saling menghargai.

Nilai kekristenan pada dasarnya sangat tidak bertentangn dengan nilai Pancasila. "Kasih" adalah kunci dari sebuah hubungan social. Hal ini selaras dengan nilai Pancasila

\footnotetext{
${ }^{5}$ Muhammad 'Ainun Yaqin. Dzikir Manaqib moderasi Islam di Tengah Masyarakat Multikultural.

${ }^{6}$ Sauqi Futaqi, konstruksi moderasi islam (wasathiyyah) dalam kurikulum pendidikan islam.
} 
yang mengharuskan seluruh rakyat Indonesia menghargai dan menghormati satu dengan yang lainnya. Dapat disimpulkan bahwa nilai kekristenan adalah ajaran yang moderat.

\section{Radikalisme}

Istilah radikalisme berasal dari Bahasa latin "radix" yang artinya akar, pangkal, bagian bawah, atau bisa juga berarti menyeluruh, habis-habisan dan amat keras untuk menuntut perubahan (KBBI) (2008:1151). Radikalisme berarti: (1) paham atau aliran yang radikal politik; (2) paham atau aliran yang menginginkan perubahan atau pembaharuan sosial dan politik dengan cara kekerasan atau drastis; (3) sikap ekstrem dalam aliran politik. (Kemenag, 2014:3) radikalisme adalah prinsip-prinsip atau praktik-praktik yang dilakukan secara radikal. Suatu pilihan tindakan yang umumnya dilihat dengan mempertentangkan secara tajam antara nilai-nilai yang diperjuangkan oleh kelompok (aliran) agama tertentu dengan tatanan nilai yang berlaku atau dipandang mapan pada saat itu.Radikalisme terus berkembang, mulai dari radikalisme klasik sampai kepada islam konteporer yang diwakili Hizbut Tahrir. Fenomena radikalisme islam diyakini sebagai ciptaan abad 20 di dunia muslim, terutama di Timut Tengah, sebagai produk dari krisis identitas yang berujung pada reaksi dan resistensi terhadap Barat yang melebarkan kolonialisasi di dunia muslim. Terpecahnya dunia Muslim ke dalam berbagai negara bangsa (nation- state) dan proyek modernisasi yang dicanangkan oleh pemerintah baru berhaluan Barat mengakibatkan umat Islam merasakan mengikisnya ikatan agama dan moral yang selama ini mereka pegangi secara kuat (Dekmejian, 1985: 25- 36) Hal ini menyebabkan munculnya gerakan-gerakan Islam radikal yang menyerukan kembali ke ajaran Islam yang murni sebagai jalan keluar. Tidak sampai disitu, gerakan ini melakukan perlawanan terhadap rezim yang dianggap sekuler dan menyimpang dari agama.
Afdhal menjelaskan bahwa gerakan radikaslisme muncul di Indonesia karena dipicu oleh persoalan domestik dan konstelasi politik internasional yang dinilai telah memojokkan kehidupan sosial politik umat islam. Kemelut domestik seperti pembantaian kyai dengan berkedok dukun santet sampai tragedy Poso (1998), tragedy Ambon (1999). Sri Yunanto menambahkan adanya gerakan militan dimana gerakan Islam yang cenderung menekankan kepada dimensi politik dan keamanan. Dalam dimensi politik dapat dicernati dari kasus-kasus penekanan terhadap gerakan menekan kebijakan implementasi syariat islam, pemberantasan kemungkaran, isu-isu tentang negara islam (aldaulah al Islamiyah). Dimensi keamanan dilihat dari kasus keterlibatan suatu kelompok radikal dalam konflik di beberapa daerah di Indonesia dan Asia Tenggara dan keterkaitannya dengan isu-isu terorisme.

Adapun kelompok-kelompok radikal tersebut secara detail dijelaskan M. Zaki Murbarok dalam penelitiannya. Dimana kelompok-kelompok Islam Radikal di Indonesia antara lain seperti KISDI (Komite Indonesia untuk Solidaritas dunia Islam), Laskar Jihad, Forum Pembela Islam, Majelis Mujahidin. M. Ridwan al- Makasary dan Ahmad Gaus A.F (2009:76) menambahkan bahwa radikalisme disemaikan di masjid-masjid.

Jamhari dan Jahroni (2004: 2-3), Islam radikal mengacu kepada "kelompok yang mempunyai keyakinan ideologis tinggi dan fanatik yang mereka perjuangkan untuk menggantikan tatanan nilai dan system yang sedang berlangsung." Dari perspektif ini, ada tiga kecenderungan umum radikalisme. Pertama, radikalisme merupakan respon terhadap kondisi yang sedang berlangsung. Biasanya respons tersebut muncul dalam bentuk evaluasi, penolakan atau bahkan perlawanan. Kedua, radikalisme tidak berhenti pada upaya penolakan, melainkan terus berupaya mengganti tatanan tersebut dengan suatu bentuk tatanan lain. Ketiga, kuatnya keyakinan kaum radikalis akan kebenaran program atau ideology yang mereka bawa. Sikap ini pada saat yang sama dibarengi dengan penafian kebenaran sistem lain yang akan diganti (Bahtiar Effendy, 1998:1213).

Sumanto dalam pengamatannya memberikan pendapat bahwa masyarakat harus 
bersatu menghadapi kelompok radikal yang suka membuat kekerasan dan intoleransi. "Di masyarakat Indonesia, ada banyak sekali masyarakat yang sangat toleran. Mereka ini hidup dalam ke-bhinekaan. Namun ada sekelompok kecil, yang suka sekali dengan kekerasan dan intoleransi serta radikalisme. Atas nama kebebasan demokrasi, kelompok intoleran dan radikal ini kerap memaksa kehendak. Atas fenomena ini, seluruh elemen harus bersatu," 7 Terkait dengan radikalisme dan intleransi ini, Sumanto menyoroti beberapa hal. Di antaranya mengenai kurikulum di sekolah. Menurutnya, kurikulum di sekolah harus mengajarkan adanya toleransi. Jika ada guru yang terpapar radikalisme harus dibereskan. Selain itu, kelompok intoleran, jangan diberi ruang sedikitpun, apalagi masuk ke ruang publik. Termasuk masjid yang selama ini menjadi salah satu tempat kelompok ekstrem tersebut melakukan provokasi atas nama agama. Selain itu partai politik dalam berpolitik tidak mengeksploitasi agama demi tujuan politiknya. ${ }^{8}$

Hasil penelitian Sumanto juga menjelaskan minimnya kelompok intelekmoderat Indonesia, khususnya Muslim, yang menyuarakan toleransi, pluralisme, moderatisme, perdamaian dan seterusnya, khususnya melalui "medsostual" (media sosial-virtual) dan "dumay" (dunia maya).

Sumanto berpendapat bahwa kaum intelek moderat terkesan malas untuk menyuarakan hasil pengkajian mereka tentang ajaran moderat. Sedangkan kelompok lain sangat gencar menyuarakan gagasan-gagasan yang merusak persatuan. Dunia media social berbasis internet sangat efektif bagi penyebaran ide-ide tersebut. Sehingga radikalisme berkembangbiak sangar cepat. Hal ini disebabkan karena kaum cendikiawan islam moderat lebih memilih untuk diam dan mencari tempat yang aman.

Radikal dalam kontek individu, dapat dikategorikan menjadi dua. Kelompok

\footnotetext{
7 Sumanto Qurtuby dalam dialog Kebangsaan bertema "Indahnya Keberagaman Menuju Indonesia Maju" di Bogor, Sabtu (10/08/2019).
}

pertama adalah orang-orang yang hanya ikutikutan. Dalam hal ini mereka turut bersuara keras oleh karena mengikuti seorang figure tertentu, namun tidak memiliki pemahaman akan apa yang mereka suarakan sendiri. Kelompok kedua adalah orang-orang yang berlaku ekstrem. Tugas mereka adalah "mengedukasi kelompok pertama yang notabene adalah kelompok orang yang tidak memiliki fondasi intelektual dan tidak stabil. Dengan demikian dapat disimpulkan bahwa masyarakat Indonesia memiliki ciri khas yang mudah terpesona pada segala sesuatu yang asing, sehingga sangat mudah untuk dipengaruhi.

Berbagai fenomena ikut-ikutan terjadi. Sebagai contoh dalam sikab beragama, seperti berjubah dan berjenggot menjadi tren yang menarik. Orang-orang ikut-ikutan tanpa mengerti maksud mereka melakukan hal tersebut. hal demikian menjadi keliru jika seseorang tidak bisa memilah aspek budaya dan aspek politik dari esensi agama, yang kemudian melakukan pemaksaan kepada orang lain supaya mengikuti. Sumanto menegaskan bahwa setiap orang harus belajar memahami orang lain dari perspektif orang lain, menghargai keanekaragaman ekspresi keagamaan dan kebudayaan masyarakat. Hendaknya sikap pluralis dimulai dari kemauan untuk memperbesar persamaan dan memperkecil perbedaan. hal ini dapat diupayakan dengan berusaha mengelaborasi pemahaman dari mazhab-mazhab yang beranekaragam. Inilah yang terjadi dalam konteks muslim di Indonesia. Jika mungkin di Indonesia jarang ditemukan sikap radikalisme yang berasal dari kelompok Kristen, namun hal ini merupakan gerakan yang harus ditanggulangi oleh seluruh golongan di wilayah negara kesatuan republic Indonesia. Orang Kristen harus berkontribusi membawa Indonesia kearah yang lebih baik terutama dalam menjalin kesatuan dan persatuan bangsa.

Agama sebagai sebuah keyakinan secara hakiki bersifat pribadi. Dalam hal ini berarti tiap individu secara menerapkan tindakan yang bersifat universal. Artinya, bersentuhan dengan alam, lingkungan dan sesama. Untuk itu, dalam

\footnotetext{
${ }^{8}$ https://www.dutaislam.com/2019/08/sumanto-alqurtuby-usul-kelompok-radikal-di-indonesia-disikathabis.html
} 
perilaku hidup beragama menyejarah diperlukan sikap moderat. Sikap moderat merarti memiliki: keterbukaan yaitu hidup menyejarah; kebebasan berpikir yaitu penalaran dalam hidup beragama; limitasi yaitu keterbatasan kemampuan pikir manusia; kerendahan hati yaitu pemahaman keagamaan disampaikan, diaplikasikan dan diterapkan dengan kerendahan hati; dan kemanusiaan yaitu, keagamaan dalam konteks Kemanusiaan - Keindonesiaan.

\section{Sikap Lembaga Kristen dalam menangkal radikalisme \\ Moderasi dan radikalisme di} Indonesia sering muncul di kalangan umat islam. Kekristenan di kenal dengan ajaran yang damai. Namun tidak menutup kemungkinan bahwa di dalam tubuh gereja juga ada pandangan ekstrem yang tidak memiliki toleransi terhadap keyakinan yang lain. Oleh karena itu Gereja perlu terus menggali ajaran Kristus yang penuh kedamain yang dapat diaplikasikan juga dalam nilai luhur Pancasila. Pancasila adalah de-confessuinal basis of the Indonesian state- yaitu dasar negara yang tidak terkait eksplisit dengan agama tertentu. $^{9}$

Dalam hal ini Kementrian Agama memiliki posisi strategis dalam mengayomi dan membina umat dalam menjalankan ajaran agamanya. Kemenag menjadi penengah dalam wujud moderasi dari kelompok ekstrem tersebut.

Menghadapi dikalisme: maka perlu pemberdayaan religious- based civil society organizations untuk penguatan komitmen kebangsaan; peningkatan peran kepemimpinan agama, sosial dan politik dalam penguatan/pemberdayaan harmoni agama-kebangsaan; pemberdayaan jaringan dan sinergi agama kebangsaan.

Lembaga agama Kristen baik gereja maupun sekolah-sekolah tinggi teologi, dan Lembaga pelayanan Kristen lain harus: (1) tidak boleh lepas dari "teks" alkitab; (2) harus bertugas untuk memelihara, melindungi dan mengajarkan mendewasakan umat jemaat dengan

\footnotetext{
${ }^{9}$ Azyumardi Azra, Harmoni agama, Kebangsaan dan Pancasila, (Yogyakarta: UGM: 2019), 1.
}

"kebenaran Teks"; (3) harus berprinsip "Pluralitas" Agama dan masyarakat.

Seluruh rakyat juga harus memelihara dan melestarikan "integrasi bangsa Indonesia" dalam sebuah keputusan, sikap dan perbuatan sadar demi Indonesia yang berhakikat, terhormat dan bermartabat dengan menjunjung tinggi nilai empat pilar kebangsaan.

\section{DAFTAR PUSTAKA}

Prasetyo, Jurnal of Proceedings Series: Prosiding SEMATEKSOS 3 "Strategi Pembangunan Nasional MenghadapiRevolusiIndustri 4.0" . No 5 (2018). Hal 22-27

Arief Budiman, (Kolom pakar: Industri 4.0 vs Sosiety 5.0). http://ft.ugm.ac.id/kolompakar-industri-4-0-vs-society-5-0/ $11 \mathrm{Feb}$ 2019

Achmad Yusuf; Jurnal Pendidikan agama islam Moderasi Sufistik atas Pluralitas Agama

Nur Kolis. Jurnal pemikiran keislaman dan Kemanusiaan BO. 1 No 2 Oktober 2017. 166-180

Muhammad 'Ainun Yaqin. Dzikir Manaqib moderasi Islam di Tengah Masyarakat Multikultural.

Sauqi Futaqi, konstruksi moderasi islam (wasathiyyah) dalam kurikulum pendidikan islam.

Sumanto Qurtuby dalam dialog Kebangsaan bertema "Indahnya Keberagaman Menuju Indonesia Maju" di Bogor, Sabtu (10/08/2019).

https://www.dutaislam.com/2019/08/sumantoal-qurtuby-usul-kelompok-radikal-diindonesia-disikat-habis.html

Azyumardi Azra, Harmoni agama, Kebangsaan dan Pancasila, (Yogyakarta: UGM: 2019), 1.

Alkitab TB LAI

Soetarman, Seminar Pertumbuhan Gereja (Jakarta: Panitia SPG, 1989) 